\title{
Factors Affecting Pediculosis Capitis Prevention at Islamic Boarding School in Indonesia
}

\author{
Kristiawati \\ Department of Maternity and Child \\ Faculty of Nursing Universitas Airlangga \\ Surabaya, Indonesia \\ kritstiawati@fkp.unair.ac.id
}

\author{
Praba Diyan Rachmawati \\ Department of Maternity and Child \\ Faculty of Nursing Universitas Airlangga \\ Surabaya, Indonesia \\ praba-d-r@fkp.unair.ac.id
}

\author{
Rum Setyowati \\ Rumah Sakit Umum Daerah Dr. Soetomo \\ Surabaya, Indonesia \\ rumsetyowati123@gmail.com
}

\begin{abstract}
Boarding school is a place where students gather to learn and stay in a dormitory. It makes boarding school become a place where diseases transmit easily, one of which is Pediculosis capitis. Various problems occur from this disease such as lack of confidence, negative social stigma, lack of sleep quality, learning disorders, and secondary infection. Although some efforts in preventing its transmission had been conducted, the incidence and negative impacts of Pediculosis capitis are still common. The purpose of this study was to identify the factors associated with prevention of Pediculosis capitis at boarding school. This study used a cross-sectional design. The population consisted of 60 female students from one of Islamic Boarding School in Indonesia. Purposive sampling was used to select 52 respondents who fit the research criteria. The independent variables were the knowledge, behavior, beliefs, environment, health, and health officers. The dependent variable was the prevention of Pediculosis capitis. Data was collected by using a questionnaire and analyzed by Spearman rho rank $(p=0.05)$. There were several factors which had significant impact on Pediculosis capitis prevention, namely knowledge $(p=0.019)$, behavior $(p=0.032)$, environment $(p=0.007)$, and health officers $(p=0.002)$. Knowledge, attitude, environment and health officers influenced the prevention of Pediculosis capitis in boarding school. Health officers were the most powerful factor in affecting the Pediculosis capitis prevention at Islamic boarding school. Further studies are recommended to examine interventions to improve the skills of health officers.
\end{abstract}

Keywords—Islamic boarding school; Pediculosis capitis

\section{INTRODUCTION}

Pediculosis capitis is a disease which is frequently found in the students worldwide [1]. Pediculosis capitis commonly infects students at boarding school due to the size of its members which is more than six person [2], and Indonesia has a unique form of Islamic boarding school well-known as Pesantren [3]. The high incidence rate of Pediculosis capitis in schools due to lack of attention from the owner, management, and the government regarding cleanliness, behavior, and care towards prevention. The custom also is another factor because they are likely to share food, bed, and clothes. Those conditions lead to the growth of Pediculosis capitis [4]. High prevalence in Islamic boarding school causes a variety of issues, such as lack of confidence, negative social stigma, lack of sleep quality, and learning disorders [5].

Islamic boarding school had been trying to prevent Pediculosis capitis using direct and indirect ways. The direct way is by avoiding the direct contact of hair in daily activity. Meanwhile, the indirect way is by avoiding to share clothes, veil, hair band, comb, towel; washing bed stuff, carpets and other goods; and by sweeping and cleaning the floors and furniture [6]. Unfortunately, those attempts were repeatedly failed in preventing recurrent infection [5]. An initial study conducted at an Islamic boarding school showed that prevention activities had been performed by the students in the form of washing their hair three times a week, combing hair with a small comb, and applying anti-parasitic lotion. However, recurrent infection of Pediculosis capitis was still common. According to the theory of Precede-Proceed Model by Lawrence Green [7], the health behavior is determined by a predisposing factor, enabling factor, and reinforcing factor. The predisposing factors include knowledge, behaviors, and belief, the enabling factors are the environment and health facilities of the boarding school, and the reinforcing factor is the role of the health officers. However, the phenomenon regarding the factors causing the failure of Pediculosis capitis prevention has not been explained yet.

Prevalence of Pediculosis capitis in the United States has shown a significant number of 12 million people annually [8]. Regarding the gender, women have greater risk compared with men $[4,5]$. The ratio of Pediculosis capitis for students in Thailand ranged from $12.26 \%$ to $29.76 \%$. The range for the age group of 12 years old was at $26.07 \%$ while the ratio for eight years age group increases at $55.89 \%$ [11]. The prevalence of Pediculosis capitis in two Islamic boarding school for girls in Jakarta were at $40.2 \%$ and $47.5 \%$, while the prevalence in an Islamic boarding school in Yogyakarta was at $71.3 \%$ [5]. Based on previous data on an Islamic boarding school in Malang, Indonesia, the total of 20 students who share bedroom 
had Pediculosis capitis, with two students (10\%) experienced secondary infection of pus and crusts. This study focused on female students who were in junior high school because the Pediculosis capitis usually infects teens, especially junior high school students. Similarly at boarding school in Jombang, which 50 respondents (100\%) are suffering Pediculosis capitis [12]. The admission period into junior high school is a transition period where a girl is learning to adjust their life from childhood to adolescence. This process affects the behavior of self-care, including efforts to prevent the disease like Pediculosis capitis [4].

Prevention, eradication, and treatment of Pediculosis capitis in traditional Islamic boarding school are still insufficient resulting in high incidence rate. The Pediculosis capitis causes clinical symptoms such as itching, leads to scalp disorders and secondary infections due to uncontrolled scratching [6]. Children with chronic Pediculosis capitis may suffer from anemia which causes them to feel lethargic, sleepy and affect their performance in the classroom and soft skill. In addition, children also have difficulty in sleeping pattern, and it makes them feel embarrassed. The incidence of Pediculosis capitis causes various problems, namely: lack of confidence, negative social stigma, lack of sleep quality, parental anxiety, and learning disorders [5]. The Pediculosis capitis is often ignored as other diseases have more priorities based on the harmfulness effects and mortality [13]. The treatment using insecticides or pediculicides is most effective, but it has side effects and increases resistance rates [6].

Based on the preliminary study at one of the Islamic boarding schools located in Malang, there was a common phenomenon that 20 people inhabited a room which is only

TABLE I. CROSS-TABULATION BETWEEN FACTORS AND PREVENTION OF PEDICULOSIS CAPITIS

\begin{tabular}{|c|c|c|c|c|c|c|c|c|}
\hline \multirow{3}{*}{ Factors } & \multicolumn{6}{|c|}{ Prevention } & \multirow{2}{*}{\multicolumn{2}{|c|}{ Total }} \\
\hline & \multicolumn{2}{|c|}{ Poor } & \multicolumn{2}{|c|}{ Moderate } & \multicolumn{2}{|c|}{ Good } & & \\
\hline & $n$ & $(\%)$ & $n$ & $(\%)$ & $n$ & $(\%)$ & $n$ & $(\%)$ \\
\hline \multicolumn{9}{|c|}{ Knowledge } \\
\hline Poor & 5 & (10.0) & 0 & $(0.0)$ & 1 & $(2.0)$ & 6 & (12.0) \\
\hline Mdrate & 4 & $(8.0)$ & 9 & (18.0) & 1 & $(2.0)$ & 14 & $(28.0)$ \\
\hline Good & 7 & (14.0) & 14 & $(28.0)$ & 12 & $(20.0)$ & 32 & $(60.0)$ \\
\hline Total & 16 & $(32.0)$ & 22 & $(44.0)$ & 14 & $(24.0)$ & 52 & $(100.0)$ \\
\hline \multicolumn{9}{|c|}{ Behavior } \\
\hline Poor & 3 & $(6.0)$ & 2 & $(4.0)$ & 0 & $(0.0)$ & 5 & (10.0) \\
\hline Mdrate & 6 & (12.0) & 16 & $(32.0)$ & 6 & (12.0) & 28 & $(56.0)$ \\
\hline Good & 7 & $(14.0)$ & 5 & $(10.0)$ & 8 & $(12.0)$ & 19 & $(34.0)$ \\
\hline Total & 16 & $(32.0)$ & 22 & $(44.0)$ & 14 & $(24.0)$ & 52 & $(100.0)$ \\
\hline \multicolumn{9}{|c|}{ Belief } \\
\hline Mdrate & 6 & (12.0) & 17 & $(34.0)$ & 3 & $(4.0)$ & 26 & $(50.0)$ \\
\hline Good & 7 & $(14.0)$ & 5 & $(10.0)$ & 11 & $(20.0)$ & 23 & $(44.0)$ \\
\hline Total & 16 & $(32.0)$ & 22 & $(44.0)$ & 14 & $(24.0)$ & 52 & $(100.0)$ \\
\hline \multicolumn{9}{|c|}{ Environment } \\
\hline Poor & 11 & $(22.0)$ & 5 & $(10.0)$ & 1 & $(2.0)$ & 17 & $(34.0)$ \\
\hline Mdrate & 1 & $(2.0)$ & 12 & $(24.0)$ & 7 & (12.0) & 20 & $(38.0)$ \\
\hline Good & 4 & $(8.0)$ & 5 & $(10.0)$ & 6 & $(10.0)$ & 15 & $(28.0)$ \\
\hline Total & 16 & $(32.0)$ & 22 & $(44.0)$ & 14 & $(24.0)$ & 52 & $(100.0)$ \\
\hline \multicolumn{9}{|c|}{ Health Facility } \\
\hline Poor & 1 & $(2.0)$ & 1 & $(2.0)$ & 0 & $(0.0)$ & 2 & $(4.0)$ \\
\hline Mdrate & 8 & (16.0) & 4 & $(8.0)$ & 6 & $(8.0)$ & 18 & (32.0) \\
\hline Good & 7 & $(14.0)$ & 17 & $(34.0)$ & 8 & $(16.0)$ & 32 & $(64.0)$ \\
\hline Total & 16 & $(32.0)$ & 22 & $(44.0)$ & 14 & $(24.0)$ & 52 & $(100.0)$ \\
\hline \multicolumn{9}{|c|}{ Health Officers } \\
\hline Poor & 7 & $(14.0)$ & 1 & $(2.0)$ & 0 & $(0.0)$ & 8 & (16.0) \\
\hline Mdrate & 5 & (10.0) & 5 & (10.0) & 6 & $(8.0)$ & 16 & $(28.0)$ \\
\hline Good & 4 & (8.0) & 16 & (32.0) & 8 & (16.0) & 28 & (56.0) \\
\hline Total & 16 & (32.0) & 22 & (44.0) & 14 & (24.0) & 52 & (100.0) \\
\hline
\end{tabular}

fifteen square meter in size. The students slept side by side in the same room and took a shower in the same bathroom. The students had already known about modes of transmission and prevention from Pediculosis capitis, but its incidence was still high. Based on the problems above, the researchers were interested in studying "Factors affecting the Pediculosis capitis prevention at Islamic Boarding School in Indonesia” by using the Behavior Theory of Lawrence Green.

\section{MethOD}

This study used a cross-sectional survey. The population was 60 female students at an Islamic Boarding School located in Malang, Indonesia, while the sample was 52 respondents chosen by purposive sampling. The independent variables were knowledge, behavior, beliefs, environment, health facility, and health officers. The dependent variable was Pediculosis capitis prevention. Questionnaires were used to collect data from participants. The questionnaires were adapted from Lawrence Green Theory and Preventing Implementation Guidance from Center Disease Control United States (2013). The study was conducted from 15 to 22 January 2017. The ethical clearance was approved by Faculty of Nursing Universitas Airlangga No. 315-KEPK issued on January 23rd, 2017.

\section{RESULTS}

All of the results is described in Table 1. It shows that more than half of respondents who had moderate knowledge $(n=14)$ also had moderate prevention effort $(n=8)$, while almost all respondents with poor knowledge $(n=6)$ had poor prevention effort $(n=5)$. It indicates that children with better knowledge will have better prevention practice. Nearly half of the respondents with moderate behavior $(n=28)$ had moderate prevention effort $(n=16)$. The data shows that children with better behavior will have better control on prevention of Pediculosis capitis. Furthermore, more than a half of respondents who had a moderate belief $(n=26)$ will do moderate prevention, while all of the respondents who had a poor belief $(n=3)$ had poor prevention. However, the respondents who had a good belief did not reflect the consistency of the prevention effort. It shows that there was no relationship between belief and the prevention of Pediculosis capitis. Most of the respondents who stated that boarding school environment was moderate $(n=20)$ would practice prevention efforts in moderate category $(n=12)$, while more than half of respondents who felt poor environment at boarding school $(n=17)$ affected on poor prevention efforts $(n=11)$. It shows that the better perception of the boarding school's environment can increase prevention efforts. Almost half of respondents with good health facility $(n=32)$ had moderate prevention behavior $(n=17)$, while a small portion of respondents with health facility related to poor prevention. Almost half of respondents who had good access to health officers $(n=52)$ had moderate prevention behavior $(n=22)$, while almost all respondents with poor relation with health officers $(n=8)$ had poor prevention behavior $(n=7)$.

TABLE II. SPEARMAN RANK AND CORRELATION COEFFICIENT

\begin{tabular}{lcc}
\hline \multicolumn{1}{c}{ Factors } & P (Sig) & R \\
\hline Knowledge & 0.019 & 0.330 \\
Behavior & 0.032 & 0.303 \\
Belief & 0.498 & 0.098 \\
Environment & 0.007 & 0.379 \\
Health Facility & 0.136 & 0.241 \\
Health officers & 0.002 & 0.429 \\
\hline
\end{tabular}




\section{DISCUSSION}

The results of data analysis showed that knowledge, behavior, environment and health officers have significant relationships with the prevention of Pediculosis capitis at the Islamic boarding school. However, the belief and health facility did not have any correlation with the prevention.

Respondents who had good knowledge would make a moderate effort to prevent Pediculosis capitis, while a small portion of respondents who were poor of knowledge performed poor prevention. It shows that knowledge influence the Pediculosis capitis prevention. The knowledge provide information and awareness which occurs after a person have sense on a specific object.Without the knowledge, a person is unable to make decisions and take action on the problems encountered [14]. Knowledge will empower students with the ability to make decision to behave clean and healthy. It corresponds with a study which conclude that the knowledge had an influence on the incidence of Pediculosis capitis, students with good knowledge about the prevention of transmission of Pediculosis capitis tend to avoid activity leading to Pediculosis capitis [5].

Information is resources to enhance the students' knowledge about prevention of Pediculosis capitis. The main resources of information for them is from health officers. The health officers play an important role in implementing health education including disease Pediculosis capitis. The respondents from this study also received some information about health and hygiene, especially from subject materials at school such as Biology. It corresponds with a study that conclude health education is very important to reduce Pediculosis capitis [15]. Although the students understood the Pediculosis capitis, they still did not know how to prevent by identifying their activities such as washing clothes, bed stuff, carpet, sweeping and cleaning the floor. It indicates that respondents only knew the concept of Pediculosis capitis but have not known about prevention.

The result showed that there were seven respondents with poor prevention despite having good knowledge. Nevertheless, there was a respondent who had poor knowledge but she had good prevention. The result of identification data which seven respondents with good knowledge, showed that they did not aware to prevent using stuffs together such as veil, headband, clothes, comb, towel, and bad habit in washing and drying clothes. It correspond with a study regarding factors related to the prevalence that using common comb can cause the Pediculosis capitis [16]. The bedroom was $3 \times 5$ meter filled 20 23 students, students sleep together by sharing bed stuffs. This condition was likely to interact each other directly so transmission of Pediculosis capitis can be infected by hair to hair as stated in a study related to the size of household members [2]. In addition, it is also caused by the culture of boarding school to share everything with their peers [17].

Most respondents with moderate behavior had practiced moderate prevention, while small proportion of respondents with poor behavior category practiced poorly in such prevention. It shows that the better behavior could better improve prevention of Pediculosis capitis. It is in line with the study which stated that behavioral factors have an association with the Pediculosis capitis infection [16]. A positive response towards the prevention is based on the awareness that Pediculosis capitis is a problem that affect the daily activities, this is evidence by the responses where they agreed that they are willing to prevent and treat Pediculosis capitis because they feel uncomfortable and itchy of the scalp. The behavior of the respondents from this study were not convincing as they did not believe that direct contact by sharing bed room with friends infected with Pediculosis capitis can spread to them, especially if hair come into contact with each other and sharing the pillows among them. This statement is supported by cramped room conditions and the usage of mattress together.

The correlation coefficient is $r=0.303$, which means it has weak level of relationship. Weak relationship between behavior and prevention of Pediculosis capitis is caused by the seven respondents who had good behavior in category but poor prevention. Researchers identified the reason is prevention efforts on the environmental aspect. The data indicates that although respondents had good behavior, they were not supported with adequate environmental conditions where too many students are sharing a small bed room. This statement is supported by the study which highlight about the size of shared room and the number of room members [2] as well as other environmental factors [18].

The results show the better the environment the more improvement in prevention of Pediculosis capitis. Data analysis can be concluded that there are environmental influences on prevention Pediculosis capitis at boarding school. It is supported by the study regarding environmental factors such lack of bathrooms in the house significantly affect the prevention [16]. Respondents strongly agreed on the statement that the pillows in the boarding school number is less so they had to sleep with a sharing pillow, while the least value on the statement that the bedroom was too congested. There is also a study which argued that the most contributing factor is a sanitary environment and bedroom [19].

The health officer affects the prevention Pediculosis capitis. The Islamic boarding school has administrators who have special task to provide health care especially Pediculosis capitis. Health officers in schools have a major role towards the prevention of infectious diseases, especially Pediculosis capitis [11]. Health officer at school is key role in Health Centre at Boarding School (Poskestren). As the executor, they have functions: the motivator, the encourager, the initiator of activities, as well as role models. The number of officer for each boarding should be at least $3 \%$ of the number of students or depend on the needs and activities.

Health officers have a role to change the behavior of female students. The principle of poskestren also agree that it is a way for disease prevention and disease transmission [12]. The sample of Islamic boarding school employed six officers to take care and develop Poskestren. Health officers are from senior students or students who have stayed long at boarding school. The six officers are divided into 3 areas, two students asadministrator, two students as drug provision, and two students as care officer. Poskestren officers routinely walk around in every room to check if there are students who are 
sick and do counseling, such as education about Pediculosis capitis by encouraging washing three times in a week; it is not allowed to wear veil, comb, and clothes alternately. If they found a student who suffer Pediculosis capitis in the presence of scabs, the officers will cut the hair short and treat secondary wounds with ointment. The activity gives benefit directly to the behavior of students in prevention of Pediculosis capitis. Most respondents have a considerable precaution against the occurrence of Pediculosis capitis among students. The best finding is that students routinely sweep the floor and clean the room, while the least value on the statement that if students are forced to borrow the comb of other students will be immersed in hot water for 5-10 minutes beforehand.

\section{CONCLUSIONS}

Pediculosis capitis prevention efforts in boarding school are influenced by the knowledge, attitude, environment and health care officers. The most influencing factor was health care officers, while the insignificant factors were belief and health facility. Further research is expected to take an action in individual counseling intervention. The purpose is to improve the knowledge and behavior of students, to modify boarding school environment and improvement on health officers.

\section{REFERENCES}

[1] M. H. Hodjati, N. Mousavi, and M. Mousavi, "Head lice infestation in school children of a low socio- economy area of Tabriz city, Iran," African J. Biotechnol., vol. 7, no. 13, pp. 2292-2294, 2008.

[2] M. E. Falagas, D. K. Matthaiou, P. I. Rafailidis, G. Panos, and G. Pappas, "Worldwide Prevalence of Head Lice," Emerg. Infect. Dis., vol. 14, no. 9, pp. 1493-1494, Sep. 2008.

[3] M. M. E. Sari, "The Role of Learning Management of Islamic Boarding School (Pesantren) in Improvement of Their Students Religious Tolerance in West Java - Indonesia," Int. J. Innov. Appl. Stud., vol. 19, no. 1, pp. 24-32, 2017.

[4] Z. A. Rahman, "Faktor-faktor yang Berhubungan dengan Kejadian Pediculosis capitis pada Santri Pesantren Rhodlotul Quran Ssemarang," 2013.

[5] S. S. S. Alatas and S. Linuwih, "Hubungan Tingkat Pengetahuan Mengenai Pedikulosis Kapitis dengan Karakteristik Demografi Santri Pesantren X, Jakarta Timur," vol. 1, no. 1, 2013.

[6] N. I. Hardiyanti et al., "Penatalaksanaan Pediculosis capitis," Majority, vol. 4, no. 9, 2015.
[7] C. M. Porter, "Revisiting Precede-Proceed: A leading model for ecological and ethical health promotion," Health Educ. J., vol. 75, no. 6, pp. 753-764, 2016.

[8] I. Nutanson, C. J. Steen, R. A. Schwartz, and C. K. Janniger, "Pediculus humanus capitis: an update," Acta Dermatoven APA, vol. 17 , no. 4,2008

[9] N. F. M. Tohit, L. Rampal, and L. Mun-Sann, "Prevalence and predictors of Pediculosis capitis among primary school children in Hulu Langat, Selangor," Med. J. Malaysia, vol. 72, no. 1, 2017.

[10] A. Tagka et al., "Socioeconomical Factors Associated With Pediculosis (Phthiraptera: Pediculidae) in Athens, Greece," J. Med. Entomol., vol. 53, no. 4, p. 919, Jul. 2016.

[11] W. Rassami and M. Soonwera, "Epidemiology of Pediculosis capitis among schoolchildren in the eastern area of Bangkok,

Thailand," Asian Pacific Journal of Tropical Biomedicine, vol. 2 no. 11. pp. 901-904, Nov-2012.

[12] F. Wijayanti, "Hubungan Antara Perilaku Sehat Dengan Angka Kejadian Pediculosis capitis Pada Santriwati Pondok Pesantren Darul Ulum Jombang," 2007.

[13] M. P. Osuna Marco, S. Chinchilla Langeber, A. Morales Tirado, Á Cervera Bravo, and M. J. Ceñal González-Fierro, "Pediculosis capitis: Is it really an insignificant disease?|Pediculosis capitis: ¿Es algo realmente banal?," Pediatr. Aten. Primaria, vol. 18, no. 70, 2016.

[14] S. Notoatmojo, Ilmu Kesehatan Masyarakat. Jakarta: PT Rineka Cipta, 2007.

[15] M. Nazari, R. Goudarztalejerdi, and M. Anvari Payman, "Pediculosis capitis among primary and middle school children in Asadabad, Iran: An epidemiological study," Asian Pac. J. Trop. Biomed., vol. 6, no. 4, pp. 367-370, Apr. 2016.

[16] M. Moosazadeh, M. Afshari, H. Keianian, A. Nezammahalleh, and A. A. Enayati, "Prevalence of Head Lice Infestation and Its Associated Factors among Primary School Students in Iran: A Systematic Review and Meta-analysis," Osong Public Heal. Res. Perspect., vol. 6, no. 6, pp. 346-356, 2015.

[17] B. Shu and Y. Tong, "Boarding at School and Students' WellBeing: The Case of Rural China," vol. fax, no. 852405, pp. 39431209.

[18] H. Kassiri and E. Esteghali, "Prevalence Rate and Risk Factors of Pediculus capitis Among Primary School Children in Iran," Arch Pediatr Infect Dis, vol. 4, no. 1, p. e26390, 2016.

[19] I. Ma'rufi, S. Keman, and H. Notobroto, "Faktor Sanitasi Lingkungan Yang Berperan Terhadap Prevalensi Penyakit Scabies Studi pada Santri di Pondok Pesantren Kabupaten Lamongan," $J$. Kesehat. Lingkung., vol. 2, no. 1, pp. 11-19, 2005. 